\title{
Carbon Sequestration by the Above Ground Biomass Pool in the South West Mau Forest of Kenya, 1985 - 2015
}

\author{
Mathew Kiura kigomo $^{1 *} \quad$ David Mwehia Mburu ${ }^{1} \quad$ James Mwangi Kinyanjui ${ }^{2}$ \\ Aggrey Daniel Maina Thuo ${ }^{3} \quad$ Charles Ndegwa Mundia ${ }^{4}$ \\ 1.Jomo Kenyatta University of Agriculture and Technology, P.O Box 62000-00200, City Square, Nairobi, Kenya \\ 2.Karatina University, P.O Box 1957-10101, Karatina, Kenya \\ 3.Kenyatta University, P.O Box 43844-00100, Nairobi, Kenya \\ 4. Dedan Kimathi University of Technology, Private Bag - 10143, Dedan Kimathi, Kenya
}

The research is sponsored by Jomo Kenyatta University of Agriculture and Technology and National Commission for Science, Technology and Innovation Kenya.

\section{Abstract}

Forests are important for regulation of the global carbon balance. Increase in forest biomass enhances atmospheric carbon sequestration while decrease in forest biomass contributes to carbon dioxide emissions. World over, forest biomass has been declining due to forest loss and degradation. The South West Mau has experienced significant forest loss since 1964. The decline is posited to have significant impacts on carbon sequestration, carbon storage, carbon dioxide emissions and status of atmospheric carbon dioxide. This study assessed interannual trend and variability as well as change point detection in carbon sequestration in South West Mau Forest, Kenya between 1985 and 2015. Above ground biomass carbon sequestration was quantified based on the Carnegie-Ames-Stanford Approach (CASA) and carbon fraction for tropical climate domain. Carbon sequestration dynamics were characterized by increase-decrease cycles of approximately 3 years and low interannual variability $(C V=9.13)$. It emerged that South West Mau Forest was a net carbon emitter with a carbon sequestration balance of -588.40 $\mathrm{Kg} /$ ha between 1985 and 2015.

Keywords: Forest, Carbon sequestration, Carnegie-Ames-Stanford Approach, Above ground net primary production

DOI: $10.7176 / \mathrm{JEES} / 10-8-05$

Publication date:August $31^{\text {st }} 2020$

\section{Introduction}

Forest represents the largest terrestrial carbon sink and accounts for approximately $90 \%$ of all living terrestrial biomass (Dixon et al. 1994; Bajracharya 2008; Tan et al. 2007). They store about 80 percent of all above-ground biomass (FAO 2005; IPCC 2006) and are thus important for regulation of the global carbon balance through carbon sequestration and carbon dioxide emission (Nasi et al. 2002;Backeus 2009). They act as carbon sink through the increase in cover (Ponce-Hernandez 2004; Bajracharya 2008) or as carbon source through the decrease in cover (Pareta \& Pareta 2011). Forests as carbon sinks, account for 50 percent of global carbon (Kindermann et al. 2008) capturing about 2.4 gigatonnes of carbon per year from the atmosphere (Jordan et al. 2018). According to FAO (2010) the world's forests stored 289 Gigatonnes of carbon in their biomass alone for the period 2005 to 2010 a slight increase from 283 Gigatonnes of carbon from the period 1990 to 2005. Forest biomass decreased by 1.1 Gigatonnes of carbon annually for the period 1990 - 2005, owing to continued deforestation and forest degradation (FAO 2006) and 0.5 Gigatonnes of carbon annually during the period 2005 to 2010 due to reduction in global forest area (FAO 2010). Carbon in forest biomass decreased in Africa, Asia and South America in the period 19902010, but increased in all other regions (FAO 2010). FAO (2006) and (2010) attributes the decline in forest carbon to forest loss. Although there is a correlation between forest area and fixed carbon, MA (2005) noted that the rate of decline in fixed carbon has been greater than the rate of decline in forest area. It is estimated that forestry contributes an average 6.7 billion tons of carbon emissions reductions annually, with over two-thirds of this potential coming from tropical nations (Baldwin \& Richards 2010).

Albeit forests' importance in global carbon balance forest cover is reported to be declining globally, nationally and at ecosystem level (FAO 2006; FAO 2010; Bonino 2006). According to FAO State of the World's Forests report of 2018 forest cover globally decreased from 31.6 percent of the global land area to 30.6 percent between 1990 and 2015. In the sub-Saharan Africa it decreased from 30.6 percent of the total land area to 27.1 percent between 1990 and 2015. Nelson (2008) estimated Kenya's gazetted forests cover at a total of 1.4 million hectares representing about 1.7 percent of total land area, which is way below the internationally recommended minimum of 10 percent of country forest cover and places Kenya among the countries with low forest cover of less than 3 percent of the total land area (Obare \& Wangwe 2008). Between 1990 and 2010 Kenya lost an average of 12,050 hectares or 0.32 percent annually. In total, between 1990 and 2010, Kenya lost 6.5 percent of its forest cover which corresponds to 241,000 hectares (Saatchi 2012). Forests' role in the global carbon balance depends on the succession stage, specific disturbance and or management regime and activities. All these result in temporal forest 
carbon dynamics characterized by long periods of gradual build-up of biomass, alternated with short periods of massive biomass loss. Increase in forest biomass enhances atmospheric carbon sequestration, whereas the decrease in forest biomass due to deforestation and forest degradation causes carbon dioxide emissions back to the atmosphere (Sitaula et al. 2005). Understanding the exchange of carbon dioxide between forests and the atmosphere is key to understanding and modifying the global carbon cycle (Kindermann et al. 2008; Jarvis \& Fowler 2001). Reports by FAO, UNFCCC and the Kyoto protocol indicate that the extent of forests and their growing stock reflect their amounts of biomass and carbon and have a crucial role in the context of the global carbon cycle and climate change (FAO 2010).

\section{Material and Methods}

\subsection{Study area}

The South West Mau Forest, is the largest of the block of the Mau forest complex of Kenya (Figure 1) with remnant natural forest and is classified as critical and endangered (WWF 2001). It lies on longitudes $35^{\circ} .15^{\prime} 00^{\prime}$ ' $\mathrm{E}$ and $35^{\circ} .40^{\prime} 00^{\prime}$ 'E and latitudes $0^{0} .20^{\prime} 00^{\prime}$ 'S and $0^{\circ} .45^{\prime} 00^{\prime}$ 'S. It covers an area of approximately 84000 ha (Obati 2007). It is part of indigenous montane ecosystem in Eastern Africa. It falls under the tropical climate domain and tropical montane climate region described by FAO (2001). The major trees species include Aningeria adolfi-friedericii, Strombosia scheffleri, Tabernaemontana stapfiana, Syzygium guineense, Neoboutonia macrocalyx, Olea capensis, Prunus africana and Albizia gummifera, (Bennun \& Njoroge 1999; KFWG 2008; Obati 2007). It has experienced significant forest loss from deforestation and degradation specifically from forest excision since 1964 (Matiru 2000). The decline which is directly linked to decline in forest biomass (Obati 2007), is likely to impact on forest carbon sequestration capacity, carbon storage and carbon dioxide emissions.

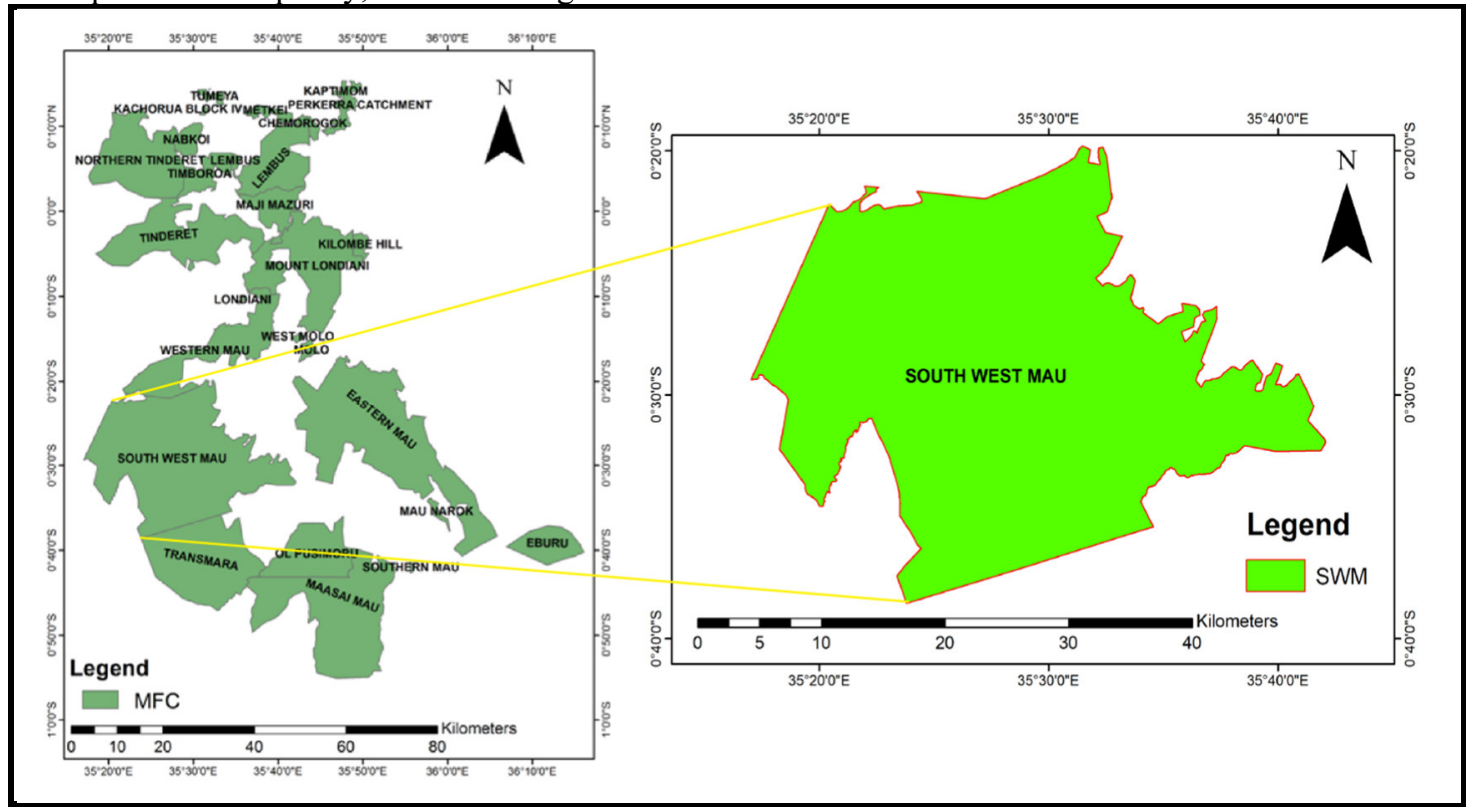

Figure 5: Location map of South West Mau Forest

\subsection{Methods}

The Carnegie-Ames-Stanford Approach (CASA) biogeochemical model was used to quantify above ground net primary production. CASA is a light use efficiency model that directly measures net primary production based on the principle that under sufficient water and field fertility, vegetation production is related to only absorbed photosynthetically active radiation. It calculates NPP as the product of fraction of photosynthetically active radiation absorbed by the canopy (FPAR), incident photosynthetically active radiation (PAR), and light use efficiency (LUE) represented in Equation 1 (Masek \& Collatz 2006; Garbulsky et al. 2008; Goerner et al. 2011; Namayanga 2002; Raza \& Mahmood 2018). Net primary production provides an accurate regular measure of biomass which subsequently is important for defining seasonal and annual terrestrial carbon fluxes (Bajracharya 2008; Bonino 2006; Lu et.al. 2002; Namayanga 2002; Rokhmatuloh 2007; Tripath et.al. 2010).The NPP was then converted into carbon using 0.47 carbon conversion fraction which is the most suitable for tropical climate domain and tropical montane climate region (Brown 1997; CMFP 2000; FAO 2001; IPCC 2006; Subedi et al. 2010).

$\boldsymbol{N P P} \equiv \boldsymbol{A G B}=\boldsymbol{F P A R} * \boldsymbol{P A R} * \boldsymbol{L U E}$

Equation 1

The fraction of photosynthetically active radiation absorbed by plants depends on the vegetation type and cover and its maximum value does not exceed 0.95 . It was directly quantified using normalized differential vegetation index (NDVI) (Glenn et al. 2008; Gabriela \& Ana Maria 2004; Goward 1989; An et al. 2013; Myeni \& Williams 
1994) as shown in Equation 2. The NDVI algorithm subtracts the red reflectance values from the near-infrared and divides it by the sum of near-infrared and red bands (Garbulsky et al. 2008; Goerner et al. 2011; Hashimoto et al. 2012; Pareta \& Pareta 2011). The normalized difference vegetation index (NDVI) data was derived as Integral normalized difference vegetation index (NDVI-I) from the NOAA AVHRR Surface Reflectance product using Google Earth Engine Code Editor. The NDVI-I is the average NDVI for each year calculated from Gridded daily normalized difference vegetation index (NDVI) data. NDVI values range from -1 to +1 . Values between 0.2 and 0.4 represent shrub and grassland, and higher values represent temperate and tropical rainforests (Holme et al. 1987; Ryan 1997). Vegetation indices studies (Loranty et al. 2018; VITO 2020; Kinyanjui 2010; Endeleo 2010; Anyamba \& Tucker 2005) observe that forest NDVI values on average range from 0.42 to 0.88 which corresponds to Fraction of photosynthetically active radiation (FPAR) values for forests which range from 0.411 to 0.780 (Field et al. 1995). As such only NDVI values above 0.42 were considered to quantify fraction of photosynthetically active radiation (FPAR) in South West Mau Forest.

$\boldsymbol{F P A R} \sim \boldsymbol{N D V I}=\frac{N E A R \text { INFRARED }-R E D}{N E A R \text { INFRARED }+R E D}$ Equation 2

Photosynthetically active radiation (PAR) is part of the incoming short-wave solar radiation that is used for photosynthesis (Namayanga 2002; Tripath et al. 2010). Approximately 45 to 50 percent of the incoming short wave solar radiation in the range of $0.4-0.7 \mu \mathrm{m}$ of the electromagnetic spectrum is generally accepted to represent Photosynthetically Active Radiation (PAR) for a 24-hour average condition (Namayanga 2002; Hasenauer et al. 2012). For tropical countries a PAR value of 0.51 or $51 \%$ of the incoming short-wave solar radiation on land is generally accepted to represent average 24 hour conditions $\left(\mathbf{K}_{\mathbf{2 4}}\right)$ for clear skies (Tripathi et al. 2010). For this study PAR was calculated at $51 \%$ of the incoming short-wave solar radiation on land as shown in Equation 3 assuming clear skies. Mean annual incoming short-wave solar radiation data generated from mean monthly incoming short-wave solar radiation data was used to compute mean annual photosynthetically active radiation (PAR). The mean monthly incoming short-wave solar radiation data was acquired from Giovanni, National Aeronautics and Space Administration Goddard Earth Science Data and Information Services Center (NASA GES DISC).

$P A R=0.51 K_{24}\left(W^{-2}\right)$

Equation 3

Growth and production by trees and stands is defined by the amount of light or radiation absorbed by leaves, the efficiency of converting absorbed light into biomass, and the allocation of photosynthate to various tissues (Binkley et al. 2011). The efficiency of converting absorbed light into biomass is referred to as Light use efficiency (LUE) and it is expressed in mass and energy units $\left(\mathrm{gC} \mathrm{Mj}^{-1}\right)$. Light use efficiency can be determined by use of agro-meteorological parameters (Namayanga 2002; Tripath et al. 2010) or by use of vegetation indices (Agapiou et al. 2012). In this study Light use efficiency (LUE) (Table 3-4) was computed using agro-meteorological parameters (Appendix 2) as shown in equation 4.

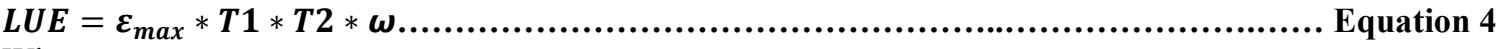

Where,

$\boldsymbol{\varepsilon}_{\max }$ is the maximum light use efficiency under ideal conditions, and the adopted value for this study was $0.389 \mathrm{gMJ}^{-}$ 1 .

T1, T2 and $\boldsymbol{\omega}$ are the limitations imposed by temperature and water stress on the optical energy utilization rate and relate to plant growth regulation (acclimation) by temperature.

$\mathbf{T} 1$ reflects the limitation imposed by the biochemical actions of plant photosynthesis at low and high temperatures and it is computed as shown in equation 5 .

$\mathbf{T} 1=0.8+0.02 * \mathbf{T}_{\mathrm{opt}}-0.0005 * \mathbf{T}_{\mathrm{opt}}{ }^{2}$

Equation 5

Where;

$\mathbf{T}_{\text {opt }}$ is the monthly average temperature in the month in which NDVI reaches maximum in a given year and a specific place. June for South West Mau has maximum NDVI.

T2 defines how light use efficiency decreases as the environmental temperatures deviates from the optimal temperature $T_{\text {opt }}$ and is computed as shown by equation 6 .

$\mathrm{T} 2=1.185 /\left(1+\mathrm{e}^{(0.2 T o p t-10-\mathrm{T})}\right) /\left(1+\mathrm{e}^{(-0.3 T \text { opt-10+T)}}\right)$

Equation 6

Where, $\mathbf{T}$ is the average annual air temperature.

The temperature data is presented in appendix 3 and described in table 3-5.

The water stress factor $(\boldsymbol{\omega})$ reflects the influence of effective water utilization by plants on the optical energy conversion rate. For this study, water stress factor $(\boldsymbol{\omega})$ was equated to evaporative fraction (Bastiaanssen $\&$ Ali 2001) and computed as shown in equation 7.

$\omega=\Lambda=\frac{L E}{L E+H}$

Where $\Lambda$ is the evaporative fraction which is defined as the energy used for the evaporation process divided by the total amount of energy available for the evaporation process, $\mathbf{L E}$ is the latent heat flux and $\mathbf{H}$ is the sensible heat flux. 


\subsection{Data analysis}

The quantified above ground carbon sequestration was subjected to time series visualization, spectral analysis and variability analysis for the period between 1985 and 2015. Time series visualization was performed to describe interannual pattern in carbon sequestration. Spectral analysis was performed to describe interannual cycling in carbon sequestration. The results from spectral analysis show whether the series varies with regular cycles (Shumway \& Stoffer 2000). Variability analysis was performed using coefficient of variability and Petit test. Coefficient of variability explained the degree of variability in inter annual carbon sequestration from 1985 to 2015 by comparing the standard deviation $(\boldsymbol{\delta})$ in the time series relative to the mean $(\mu)$ as shown in equation 8 .

$$
\boldsymbol{C V}=\frac{\delta}{\mu} \times 100
$$

Coefficient of variability $(\mathrm{CV})$ values below 10.7 percent indicated low variability, values between 10.7 percent and 15.4 percent indicated moderate or average variability, value between 15.4 percent and 17.7 percent indicated high variability, while values above 17.7 percent indicated very high variability. This classification was computed using the mean and standard deviation of coefficient of variability for above ground carbon sequestration in South West Mau forest between 1985 and 2015and based on the criteria proposed by Garcia in 1989 (Ferreira et al. 2018; Couto et al. 2013; Vaz et al. 2017). The criteria are presented in table 1. The mean and standard deviation of coefficient of variation for above ground carbon sequestration in South West Mau forest between 1985 and 2015 were 13.07 and 2.33 respectively.

Table 1: Criteria of classification of coefficient of variation

\begin{tabular}{ll}
\hline Coefficient of variation classification criteria & Classification \\
\hline $\mathrm{CV} \leq(\mathrm{A}-1 \mathrm{~B})$ & Low \\
$(\mathrm{A}-1 \mathrm{~B})<\mathrm{CV} \leq(\mathrm{A}+1 \mathrm{~B})$ & Moderate or average \\
$(\mathrm{A}+1 \mathrm{~B})<\mathrm{CV} \leq(\mathrm{A}+2 \mathrm{~B})$ & High \\
$\mathrm{CV}>(\mathrm{A}+2 \mathrm{~B})$ & Very high \\
\hline
\end{tabular}

Where $\mathrm{A}$ and $\mathrm{B}$ are the mean and standard deviation of the coefficient of variation respectively

\section{Results and discussion}

The mean carbon sequestered by the above ground pool of South West Mau forest between 1985 and 2015 was $4,611.21 \mathrm{Kg} / \mathrm{ha}$ with a standard deviation of $428.11 \mathrm{~kg} / \mathrm{ha}$. The maximum and minimum sequestered carbon were $5,294.25 \mathrm{Kg} / \mathrm{ha}$ in 1998 and 3,684.33 Kg/ha in 2009 respectively. Figure 1 below is a visualization of the time series for South West Mau forest for the period between 1985 and 2015.

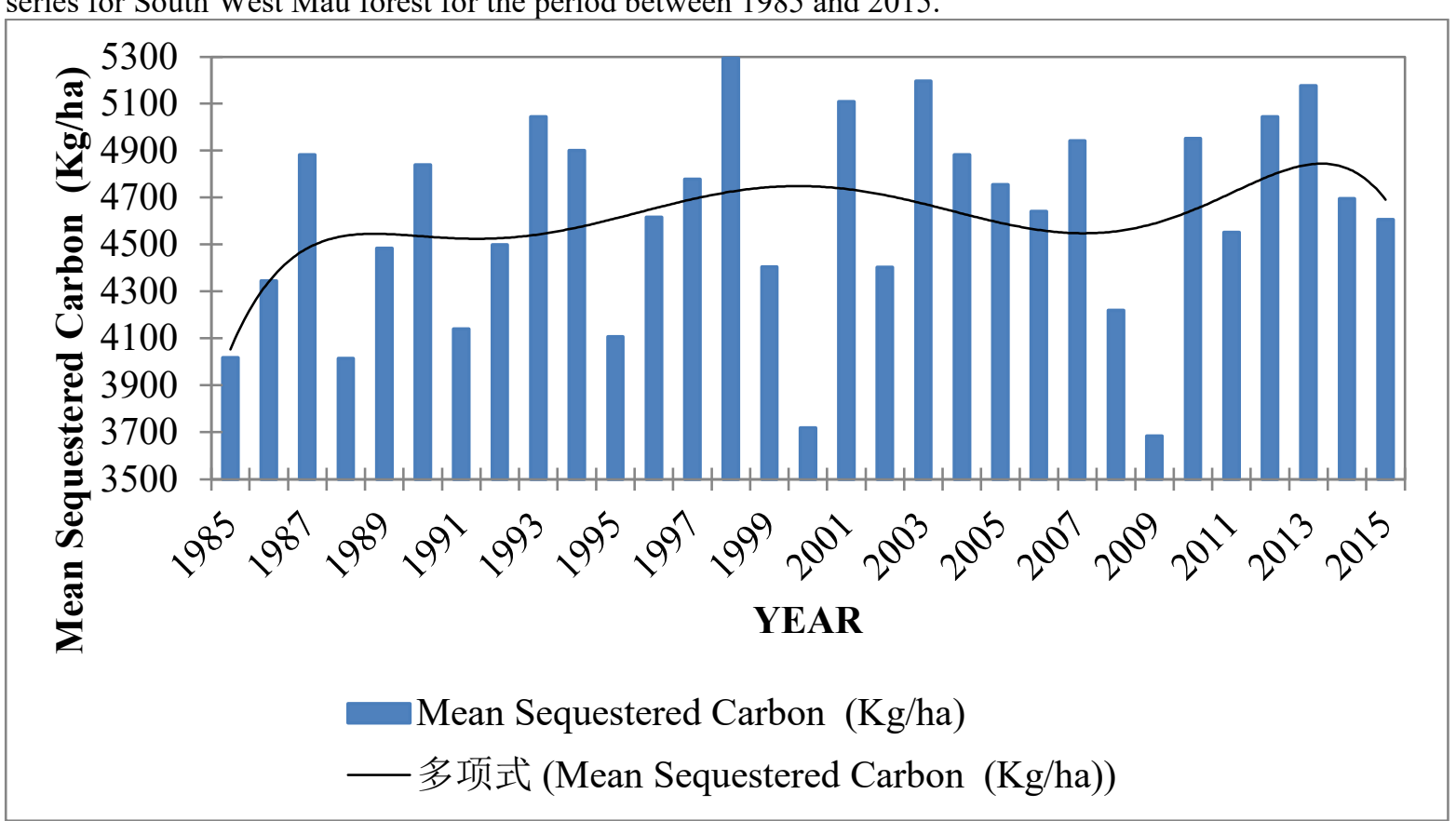

Figure 1: Mean carbon sequestration in South West Mau forest (1985-2015)

The mean annual above ground carbon sequestration in South West Mau forest fluctuated from year to year characterized by increases that saturated at some point followed by decreases. A sequence of three years increase in carbon sequestration and eventual saturation followed by a decrease between 1985 to1987, 1988 to 1990 and 1991 to 1993 was noted. There was then a sequential decrease in carbon sequestration for two year from 1994 to 1995 followed by a sequence of three year increase and eventual saturation from 1996 to 1998 and thereafter a 
decline in 1999 and 2000. From 2001 to 2004 there was an annual transposition between increases and decreases in carbon sequestration. The decrease continued from 2004 to 2009 with a one year interruption of this pattern by an increase in 2007. There was an annual transposition between carbon sequestration increase and decrease in 2010 and 2011 followed by a two years increase between 2012 and 2013 . The period between 2014 and 2015 continued to show decrease in carbon sequestration. The fluctuations in above ground carbon sequestration in the South West Mau forest had a negative balance of $-588.40 \mathrm{Kg} /$ ha for the period between 1985 and 2015 signifying that above ground biomass pool was generally a carbon emitter.

Six order polynomial trend line (Figure 1) showed that the mean annual above ground carbon sequestration in South West Mau forest for the period between 1985 and 2015 had smooth periodic oscillations depicted by the trend line equation $y=-0.0003 x^{6}+0.028 x^{5}-1.0305 x^{4}+18.192 x^{3}-158.87 x^{2}+652.38 x+3541.9$. Spectral analysis showed that the mean annual above ground carbon sequestration spectral density peak corresponded to a period of 2.8 years (Figure 2), signifying that mean annual above ground carbon sequestration in the South West Mau varied with quite regular cycles of approximately 3 years.

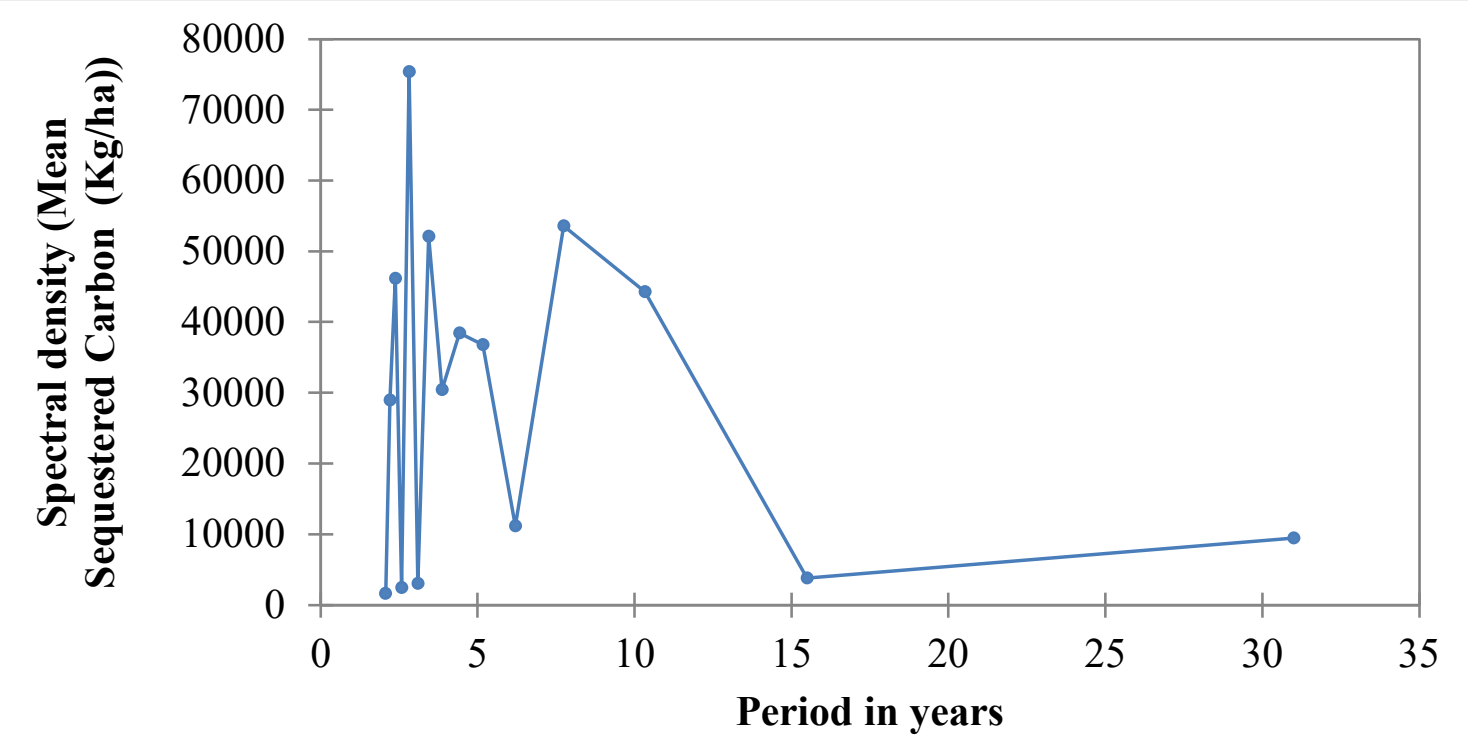

Figure 2: Periodicity of carbon sequestration in SWM Forest (1985-2015)

Coefficient of variability was at 9.13 percent indicating low variability in the interannual carbon sequestration for South west Mau Forest between 1985 and 2015. Results from Petit test showed that there was no break point in interannual carbon sequestration in the South West Mau forest between 1985and 2015 (Figure 3). The null hypothesis that data are homogenous was accepted at P-value (two tailed) equal to 0.3481 and alpha set at 0.05 .

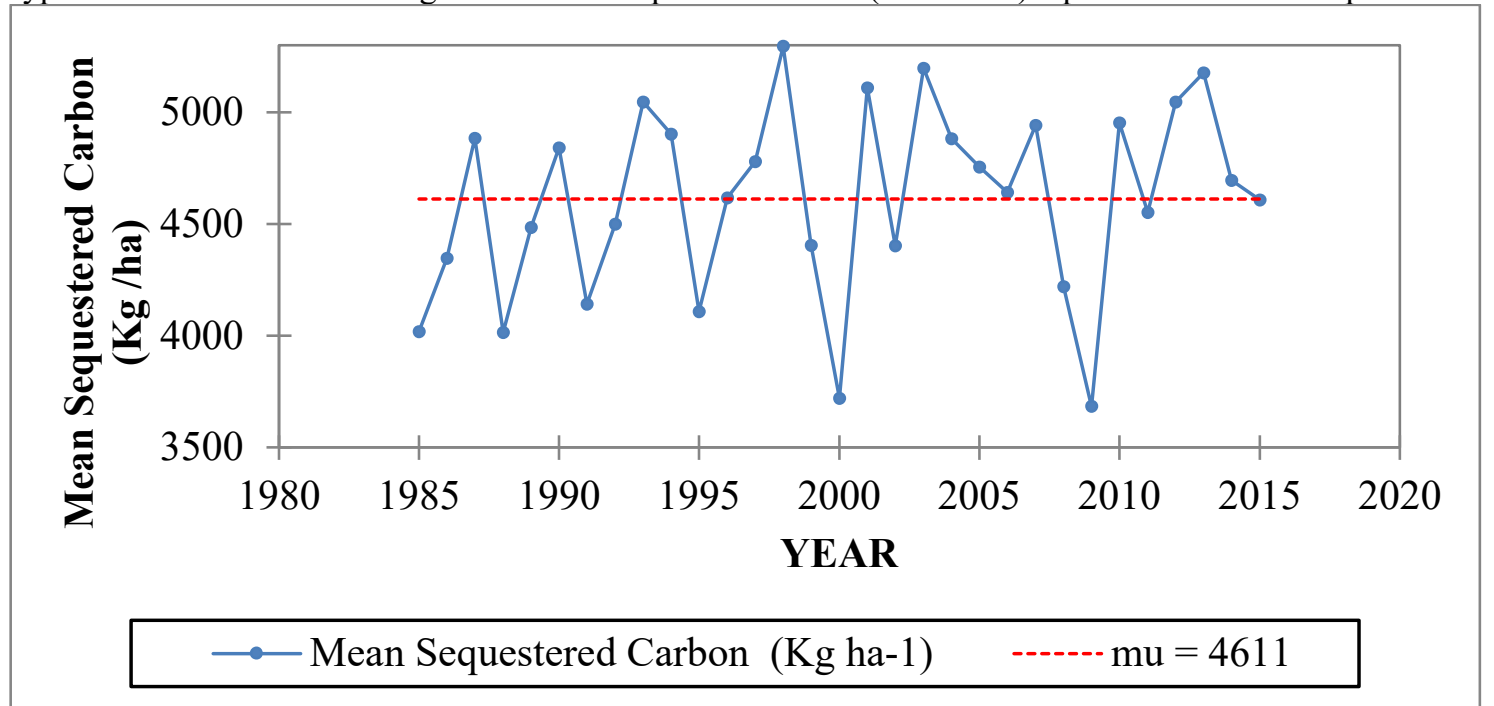

Figure 3: Change point analysis of the mean annual carbon sequestration in the South West Mau forest (19852015)

The results indicated that the above ground biomass pool of the South West Mau forest was a weak net carbon 
emitter for the period between 1985 and 2015 and that there was low year to year variability in carbon sequestration meaning. The fluctuations in carbon sequestration were associated with oscillating natural and anthropogenic disturbance and regeneration events.

\section{Conclusion}

The above ground biomass carbon stock in the South West Mau forest between 1985 and 2015 exhibited a steady monotonic upward and downward trend with a repeat cycle of approximately three years. There were occasion of sharp increases and falls in mean carbon sequestration. The steady monotonic upward and downward trend depicted year to year changes in forest structure and composition while the sharp increases and falls pointed towards occasional regeneration events and active disturbance activities such as logging, fires or conversion to other uses respectively. In general the above ground biomass pool in South West Mau Forest for the period between 1985 and 2015 was a weak net carbon emitter with low interannual carbon sequestration variability.

\section{References}

Agapiou, A., Hadjimitsis, D. G. \& Alexakis, D. D., 2012. Evaluation of broadband and narrowband vegetation indices for the identification of archaeological crop marks. Remmote sesning, Issue 4, pp. 3892-3919.

An, N., Price, K. P. \& Blair, J. M., 2013. Estimating aboveground net primary productivity of the tallgrass prairie ecosystem of the Central Great Plains using AVHRR NDVI. International Journal of Remote Sensing, 34(11), pp. 3717-3735.

Anyamba, A. \& Tucker, C. J., 2005. Analysisof Sahelian vegetation dynamics using NOAA AVHRR NDVI data from 1981 - 2003. Journal of Arid Environments, Volume 63, pp. 596 - 614.

Backeus, S., 2009. Forest management strategies for carbon dioxide mitigation, s.1.: Umea.

Bajracharya, S., 2008. Community Carbon Forestry: Remote Sensing of Forest Carbon and Forest Degradation in Nepal, Enschede, The Netherlands: International Institute for Geo-Information Science and Earth Observation.

Baldwin, L. \& Richards, K. R., 2010. Institutional Support for an International Forest Carbon Sequestration Agreement. August, pp. 10 - 41

Bastiaanssen, W. G., \& Ali, S. 2001. A New Crop Yield Forecasting Model Based onSatellite Measurements Applied Across the Indus Basin, Pakistan. Agriculture, Ecosystems \& Environment, 24.

Bennun, L. \& Njoroge, P., 1999. Important Bird Areas in Kenya. Nairobi: Nature Kenya.

Binkley, D., Campoe, O. C., Gspalti, M. \& Forrester, D., 2011. Light absorption and use efficiency in forests: Why patterns differ for trees and stands. Forest ecology and management.

Bonino, E. E., 2006. Changes in carbon pools associated with land-use gradients in the dry Chaco, Argentina.. Forest Ecology and Management, Volume 223, pp. 254-263.

Brown, S., 1997. Estimating Biomass and Biomass Change of Tropical Forests: a Primer. (FAO Forestry Paper - 134), Rome: Food and Agriculture Organization of the United Nations.

CMFP, 2000. Carbon Budget Accounting at the Forest Management Unit Level: An overview of issues and methods, Ottawa: Canadian Forest Service.

Couto, M., Peternelli, L. \& Barbosa, M., 2013. Classification of the coefficients of variation for sugarcane crops. Ciência Rural, Santa Maria, 43(6), pp. 957-961.

Dixon, R. K. et al., 1994. Carbon Pools and Flux of Global Forest Ecosystems Science. AAAS, 263(5144), p. 185190.

Endeleo, 2010. Data products. [Online] Available at: http://endeleo.vgt.vito.be/dataproducts.html [Accessed 101 $2018]$.

FAO, 2001. The status of forests: The global forest resource assessment 2000., Rome: UNFAO.

FAO, 2005. Global Forest Resources Assessment 2005 Progress towards sustainable forest management. Vol. 147 of FAO Forestry Paper, Rome: Food and Agriculture Organization of the United Nations.

FAO, 2006. Global Forest Resources Assessment 2005 - Progress Towards Sustainable Forest Management, Rome: Food and Agriculture Organization of the United Nations.

FAO, 2010. Global Forest Resources Assessment 2010, Rome: Food and Agriculture Organisation .

FAO, 2018. The State of the World's Forests 2018 - Forest pathways to sustainable development, Rome: FAO.

Ferreira, A. et al., 2018. Methods for classifying coefficient of variation in experimetnation with poultrys. Comunicata Scientiae, 9(4), pp. 565-574.

Field, C. B., Randerson, J. T. \& Malmstrom, C. M., 1995. Global Net Primary Production: Combining ecology and remote sensing. REMOTE SENS. ENVIRON, Volume 51, pp. 74-88.

Gabriela, P. \& Ana Maria, C., 2004. A test of the use of NDVI data to predict secondary productivity. Applied vegetation science, Volume 7, pp. 201-208.

Garbulsky, M. F., Penuelas, J., Papale, D. \& Filella, I., 2008. Remote estimationof carbon dioxide uptake by a Mediterranean forest. Global Change Biology, Volume 14, pp. 2860-2867. 
Glenn, E. P., Huete, A. R., Nagler, P. L. \& Nelson, S. G., 2008. Relationship Between Remotely-sensed Vegetation Indices, Canopy Attributes and Plant Physiological Processes: What Vegetation Indices Can and Cannot Tell Us About the Landscape. Sensors, Volume 8, pp. 2136-2160.

Goerner, A. et al., 2011. Remote sensing of ecosystem light use efficiency with MODIS-based PRI. Biogeoscience, Volume 8, pp. 189 - 202.

Goward, S. N., 1989. Satellite bioclimatology. Journal of climate, Volume 2, pp. 710-720.

Hasenauer, H. et al., 2012. Reconciling satellite with ground data to estimate forest productivity at national scales. Forest Ecology and Management, Volume 276, pp. 196 - 208.

Hashimoto, H. et al., 2012. Exploring Simple Algorithms for Estimating Gross Primary Production in Forested Areas from Satellite Data. Remote Sensing, Volume 4, pp. 303 - 326.

Holme, A., Burnside, D. G. \& Mitchell, A. A., 1987. The development of a system for monitoring trend in range condition in the arid shrublands of Western Australia. Australian Rangeland Journal, Volume 9, pp. 14-20.

IPCC, 2006. Guidelines for National Greenhouse Gas Inventories, s.1.: s.n.

Jarvis, P. G. \& Fowler, D., 2001. Forests and the Atmosphere. In: E. J, ed. s.1.:Blackwell Science Ltd, pp. 229 281.

Jordan, C.-M.et al., 2018. Contributionof ferest wood products to megative emissions: historical comparative analysis from 1960 to 2015 in Norway, Sweden and Finland. Carbon balance and management.

KFWG, 2008. Mau Complex and Marmanet forests: Environmental and economic contributions - Current state and trends, Nairobi: GoK.

Kindermann, G. E., McCallum, I., Fritz, S. \& Obersteiner, M., 2008. A Global Forest Growing Stock, Biomass and Carbon Map Based on FAO Statistics. Silva Fennica, 42(3), pp. 387-396.

Kinyanjui, M. J., 2010. NDVI-based vegetation monitoring in Mau forest complex, Kenya. African JOurnal of Ecology, Volume 49, pp. 165-174.

Loranty, M. M. et al., 2018. Vegetation indices do not capture forest cover variation in upland Siberain Larch Forests. Remote sensing, 10(1686).

Lu, D., Mausel, P., Brondizio, E. \& Moran, E., 2002. Above-ground Biomass Estimation of Successional and Mature forest using TM image in the Amazon Basin. Ottawa, s.n.

MA, 2005. Ecosystems and Human Well-being: Synthesis. Millenium Ecosystem Assessment, Washington, DC: Island Press.

Masek, J. G. \& Collatz, G. J., 2006. Estimating forest carbon fluxes in a disturbed southeastern landscape: Integration of remote sensing, forest inventory, and biogeochemical modelling. Journal of Geophisics, Volume III.

Matiru, V., 2000. Forest cover in Kenya, policy and practice, Nairobi: UCN-World Conservation Union.

Myeni, R. B. \& Williams, D. L., 1994. On the relationship between FAPAR and NDVI. remote sens. Environ, Volume 49, pp. 200-211.

Namayanga, L., 2002. Estimating Terrestrial Carbon Sequestered in Above ground wood biomass from Remotely Sensed data: the use of SEBAL and CASA algorithms in a semi-arid area of Serowe-Botswana, EnschedeThe Netherlands: International Institute for Geo-information Science and Earth observation.

Nasi, R., Wunder, S. \& Campos, J. J., 2002. Forest ecosystem services: can they pay our way out of deforestation?. New York, GEF.

Nelson, C., 2008. Forest Resource Outlook, Arlington: Our Task Inc.

Obare, L. \& Wangwe, J. B., 2008. Underlying Causes of Deforestation and Forest Degradation in Kenya. World Rainforest Movement Bulletin , Issue 133.

Obati, G. O., 2007. An investigation of forest ecosystem health in relation to anthropogenic disturbance in the SouthWestern Mau Forest Reserve, Kenya, s.1.: University of Bremen.

Pareta, K. \& Pareta, U., 2011. Forest carbon manaagement using satellite remote sensing techniques. A case study of Sagar District (M.P). E-International Scientific Research Journal, 3(4), pp. 335 - 348.

Ponce-Hernandez, R., 2004. Assessing carbon stocks and modelling win-win scenarios of carbon sequestration through land-use changes, Rome: FAO.

Raza, S. M. \& Mahmood, S. A., 2018. Estimation of net rice production through improved CASA model by addition of soil suitability constant. Sustainability, Volume 10, p. 1788.

Rokhmatuloh, 2007. Estimation of Carbon Stock Using Remote Sensing: A Case Study of Indonesia, Kampus: World wide Fund for Nature-Pakistan.

Ryan, L., 1997. Creating a Normalized Difference Vegetation Index (NDVI) image Using MultiSpec, Durham: OPAL/EOS

Saatchi, S., 2012. Kenya Forest Information and Data. [Online] Available at: $\mathrm{http}$ ///rainforest.mangabay.com/deforestation/2000/Kenya [Accessed 54 2012].

Shumway, R. H. \& Stoffer, D. S., 2000. Time Series Analysis and Its Applications. New York: Springer Verlag.

Sitaula, B. K., Sankhayan, P. L., Bajracharya, R. M. \& Singh, B. R., 2005. systems analysis of soil and forest 
degradation in a mid-hill watershed of Nepal using a bio-economic model Land Degradation and Development. 16(5), pp. 435-446.

Subedi, B. P. et al., 2010. Forest Carbon Stock Measurement: Guidelines for measuring carbon stocks in community-managed forests, Kathmandu: ANSAB, FECOFUN, ICIMOD, NORAD.

Tan, K., Piao, S., Peng, C. \& Fang, J., 2007. Satellite-based estimation of biomass carbon stocks for northeast China's forests between 1982 and 1999. Forest Ecology and Management, Volume 240, pp. 114-121.

Tripathi, S., Soni, S. K., Maurya, A. K. \& Soni, P. K., 2010. Calculating carbon sequestration using remote sensing and GIS. [Online] Available at: http://www.geospatialworld.net/index.php

Vaz, M., Pacheco, P., Seidel, E. \& Ansuj, A., 2017. Classification of the coefficient of variation to variables in beef cattle experiments. Ciência Rural, Santa Maria, 47(11).

VITO, 2020. Data products. [Online] Available at: http://endeleo.vgt.vito.be/dataproducts.html

WWF, 2001. East African montane forests, s.l.: s.n. 